\title{
Redox signaling through zinc activates the radiation response in Deinococcus bacteria
}

\author{
Romaric Magerand ${ }^{1}$, Pascal Rey ${ }^{2}$, Laurence Blanchard ${ }^{1}$ \& Arjan de Groot $^{1 凶}$
}

Deinococcus bacteria are extremely resistant to radiation and other DNA damage- and oxidative stress-generating conditions. An efficient SOS-independent response mechanism inducing expression of several DNA repair genes is essential for this resistance, and is controlled by metalloprotease IrrE that cleaves and inactivates transcriptional repressor DdrO. Here, we identify the molecular signaling mechanism that triggers DdrO cleavage. We show that reactive oxygen species (ROS) stimulate the zinc-dependent metalloprotease activity of IrrE in Deinococcus. Sudden exposure of Deinococcus to zinc excess also rapidly induces DdrO cleavage, but is not accompanied by ROS production and DNA damage. Further, oxidative treatment leads to an increase of intracellular free zinc, indicating that IrrE activity is very likely stimulated directly by elevated levels of available zinc ions. We conclude that radiation and oxidative stress induce changes in redox homeostasis that result in IrrE activation by zinc in Deinococcus. We propose that a part of the zinc pool coordinated with cysteine thiolates is released due to their oxidation. Predicted regulation systems involving IrrE- and DdrO-like proteins are present in many bacteria, including pathogens, suggesting that such a redox signaling pathway including zinc as a second messenger is widespread and participates in various stress responses.

For all organisms it is important to respond efficiently to changes in environmental constraints leading to stress conditions within cells. In case of DNA damage-generating stress, many bacteria use the SOS response to induce expression of DNA repair genes. The molecular signal inducing the SOS response is the presence of singlestranded DNA ${ }^{1}$. RecA filaments formed on single-stranded DNA stimulate self-cleavage and inactivation of LexA, the repressor of the SOS response. Not all bacteria use the SOS response to induce DNA repair genes ${ }^{2}$. In Deinococcus bacteria, induction of $r e c A$ and other DNA repair genes occurs in a RecA/LexA-independent manner and in the present work we aim to identify the intracellular molecular signal that induces this SOSindependent response.

Deinococcus species are famous for their extreme tolerance to DNA damage- and oxidative stress-generating conditions such as radiation and desiccation, and for their capacity to repair massive DNA damage ${ }^{3-6}$. This extreme tolerance results from a combination of multiple factors and mechanisms ${ }^{7}$, including limitation of oxidative protein damage ${ }^{8-10}$ that has been correlated with a high intracellular $\mathrm{Mn}^{2+} / \mathrm{Fe}^{2+}$ ratio (e.g. 0.24 in Deinococcus radiodurans versus $<0.01$ in radiation-sensitive Escherichia coli) ${ }^{11}$ and the accumulation of small antioxidant $\mathrm{Mn}^{2+}$-containing complexes (with intracellular $\mathrm{Mn}^{2+}$ concentrations ranging from 0.2 to $2 \mathrm{mM}, 70 \%$ of which not bound to proteins $)^{12}$. An efficient radiation/desiccation response (RDR) mechanism for induced expression of a set of genes forming the RDR regulon is also essential for radiation tolerance ${ }^{13-16}$. The predicted RDR regulon in different Deinococcus species consists of about 20 genes, including classical DNA repair genes (e.g. $r e c A, u v r B$ ) and novel genes more specific to Deinococcus (e.g. $d d r B, d d r O)^{17}$. We previously demonstrated that $\mathrm{RDR}$ regulon expression is controlled by two proteins highly conserved in Deinococcus species: IrrE and $\mathrm{DdrO}^{14}$.

IrrE, also called PprI, is a COG2856 domain-containing metalloprotease that induces expression of the RDR genes by cleaving and inactivating $\mathrm{DdrO}$, the transcriptional repressor of the RDR regulon ${ }^{14,17-20}$. DdrO has a helix-turn-helix (HTH) motif-containing DNA-binding domain of the XRE family ${ }^{19}$. The HTH_XRE-type domain is present in many transcriptional regulators and has been named after the PBSX repressor protein Xre from the defective Bacillus prophage $\mathrm{PBSX}^{21}$. DdrO cleavage has been demonstrated when IrrE and DdrO are co-expressed from plasmids in $E$. coli without exogenous stress, and in vitro with both proteins purified from $E$. coli. In Deinococcus itself, however, the cleavage is somehow induced when bacteria are exposed to radiation ${ }^{14}$. The N-terminal domain of IrrE is structurally similar to zinc metalloprotease thermolysin ${ }^{22}$, and includes the

\footnotetext{
${ }^{1}$ Aix Marseille Univ, CEA, CNRS, BIAM, Molecular and Environmental Microbiology Team, 13108 Saint Paul-Lez-Durance, France. ${ }^{2}$ Aix Marseille Univ, CEA, CNRS, BIAM, Plant Protective Proteins Team, 13108 Saint Paul-Lez-Durance, France. ${ }^{\circledR}$ email: nicolaas.degroot@cea.fr
} 
active site/metal ion binding motif HEXXH that is essential for protease activity ${ }^{14}$. No metal ion was observed in the crystal structure of IrrE, but briefly soaking apo-IrrE crystals in a $\mathrm{Zn}^{2+}$-containing solution resulted in binding of $\mathrm{Zn}^{2+}$ in the expected site, accompanied by re-orientation of the side chains of two active site residues towards the $\mathrm{Zn}^{2+}$ ion ${ }^{22}$. Addition of $\mathrm{Zn}^{2+}$ to metal-free IrrE was sufficient to restore DdrO cleavage in vitro ${ }^{17}$. The in vitro protease activity of IrrE could also be restored after addition of $\mathrm{Mn}^{2+}$ or $\mathrm{Fe}^{2+}$ ions to metal-free enzyme ${ }^{17}$. Such in vitro re-activation not only by $\mathrm{Zn}^{2+}$ but also by some other metals is commonly found for zinc metalloproteases, including thermolysin ${ }^{23,24}$. Besides its protease domain, the crystal structure of IrrE revealed an additional domain with structural similarity to GAF domains ${ }^{22}$, which may have a role in signaling or in protein-protein interactions ${ }^{25,26}$. Interestingly, predicted but largely uncharacterized COG2856/XRE protein pairs have been identified in many other bacterial genera, including pathogens and bacteria used in biotechnological industry ${ }^{14,19,27-29}$, suggesting that stress response mechanisms involving such protein pairs are more widespread than currently recognized.

The molecular signaling mechanism by which radiation triggers cleavage of DdrO by the constitutively expressed IrrE in Deinococcus is unknown. Exposure of the cells to radiation or desiccation causes redox imbalance through formation of reactive oxygen species (ROS) ${ }^{6}$. ROS can react with and damage any molecule in the cell, including DNA. In turn, DNA damage can trigger ROS production ${ }^{30}$. Besides causing damage, ROS and other reactive species may also activate proteins through oxidative post-translational modification of cysteine residues, as exemplified by chaperone Hsp33 and transcription factor OxyR in E. coli and several other bacteria ${ }^{31,32}$. Here, we investigated if ROS are involved in IrrE activation, either by direct redox modification of IrrE or indirectly by generating another molecular signal acting downstream the stress-induced ROS and redox imbalance. We show that IrrE is a zinc-dependent enzyme in vivo in Deinococcus, that induction of IrrE protease activity still occurs when IrrE lacks its GAF-like domain, and that IrrE is activated directly by increased intracellular levels of free zinc ions following a zinc shock. Moreover, an increase in free zinc and IrrE protease activation is also observed after oxidative treatment of the cells. We propose that induction of the RDR regulon by radiation and oxidative stress involves a zinc signal generated by impaired redox homeostasis. Such role for zinc as a second messenger in regulation of cellular enzyme activities has been described previously for eukaryotes ${ }^{33-35}$, but to our knowledge this is the first time for prokaryotes.

\section{Results}

DdrO cleavage in Deinococcus is stimulated by oxidative treatments. Cleavage of RDR regulon repressor DdrO (129 aa) by metalloprotease IrrE (281 aa) in D. deserti has been observed after exposure of the cells to gamma or UV radiation ${ }^{14}$. The cleavage occurs between L106 and R107 of DdrO. Here we show that this cleavage is also induced after a short exposure to mitomycin C (MMC) (Fig. 1; Supplementary Fig. S1). MMC is known in particular as an alkylating agent that generates interstrand DNA cross-links, but the metabolism of this quinone-containing antibiotic in the cell also results in oxidative damage to other macromolecules via the generation of various $\operatorname{ROS}^{6,36-38}$. The antioxidant compound thiourea scavenges hydroxyl and superoxide radicals and hydrogen peroxide $\left(\mathrm{H}_{2} \mathrm{O}_{2}\right)^{39,40}$, and has been found to inhibit the effects of the MMC-induced ROS production in E. coli ${ }^{36}$. Here we observed that the MMC-induced DdrO cleavage in D. deserti was decreased in the presence of thiourea (Fig. 1; Supplementary Fig. S1), suggesting the involvement of MMC-induced ROS in DdrO cleavage stimulation. Another antioxidant, TEMPOL, which catalyzes superoxide dismutation, facilitates catalase-like metabolism of $\mathrm{H}_{2} \mathrm{O}_{2}$ and limits hydroxyl radical formation ${ }^{41-43}$, also inhibited DdrO cleavage in cells exposed to MMC (Fig. 1). When the cells were directly exposed to $\mathrm{H}_{2} \mathrm{O}_{2}$ for $10 \mathrm{~min}$, DdrO cleavage was also efficiently induced, which was inhibited by thiourea and TEMPOL (Fig. 1), further confirming the participation of redox signaling in IrrE activation.

We first presumed that stress-generated ROS directly oxidize IrrE. The sulfur-containing amino acids methionine (Met) and cysteine (Cys) are particularly sensitive to oxidation, and fulfill a key role in redox signaling. Thus for some proteins oxidation of these residues leads to their activation (e.g. HypT, OxyR, Hsp33 ${ }^{44}$. Met and Cys residues highly conserved in deinococcal IrrE proteins were mutated in $D$. desert $i$ IrrE. None of the mutations affected radiation resistance and DdrO cleavage in D. deserti (Supplementary Fig. S2), excluding a role of these residues in IrrE activation upon stress exposure. This is in line with the previously reported in vitro cleavage of DdrO by IrrE, using purified proteins for which any modification (e.g. oxidized residues) was not detected by mass spectrometry ${ }^{14,17}$. Together, these data suggest that ROS stimulate IrrE activity in an indirect manner.

IrrE is a zinc-dependent metalloprotease in Deinococcus. DdrO cleavage by IrrE is not only stimulated by radiation and other stresses that induce ROS production, but also rapidly (within 5-10 min) and efficiently after exposure of Deinococcus cultures to an excess of zinc ions, but not of other metal ions including $\mathrm{Mn}^{2+}$ and $\mathrm{Fe}^{2+17}$, as confirmed here (Supplementary Fig. S1). The stimulation of IrrE protease activity by the zinc shock might be direct, if IrrE activity indeed requires $\mathrm{Zn}^{2+}$ as co-factor in vivo, or indirect, if the zinc shock, in common with radiation, causes ROS formation and DNA damage. To better understand the zinc shock-induced activation mechanism, we first investigated the metal dependency of the IrrE activity in vivo by applying different treatments in the presence of TPEN or dipyridyl, which are membrane-permeable chelators with high affinity for zinc $\left(\mathrm{Zn}^{2+}\right)$ and iron $\left(\mathrm{Fe}^{2+}\right)$ ions, respectively. Dipyridyl (DIP) was included in these tests because of oxidative stress through ROS formation often involves $\mathrm{Fe}^{2+}$. DIP $(500 \mu \mathrm{M})$ inhibited DdrO cleavage only in $\mathrm{H}_{2} \mathrm{O}_{2}$-exposed cells (Fig. 2; Supplementary Fig. S3), showing that the observed cleavage stimulated by $\mathrm{H}_{2} \mathrm{O}_{2}$, but not by UV or MMC, requires $\mathrm{Fe}^{2+}$, most likely via the Fenton reaction where $\mathrm{H}_{2} \mathrm{O}_{2}$ reacts with $\mathrm{Fe}^{2+}$ generating oxygen-radical species. TPEN $(25$ to $50 \mu \mathrm{M})$ totally blocked DdrO cleavage in D. deserti and D. radiodurans exposed to each of the applied treatments (Fig. 2; Supplementary Fig. S3). Additional experiments showed that adding $10 \mu \mathrm{M}$ TPEN to the culture was sufficient to inhibit stress-induced DdrO cleavage (Supplementary Fig. S3). It has been 


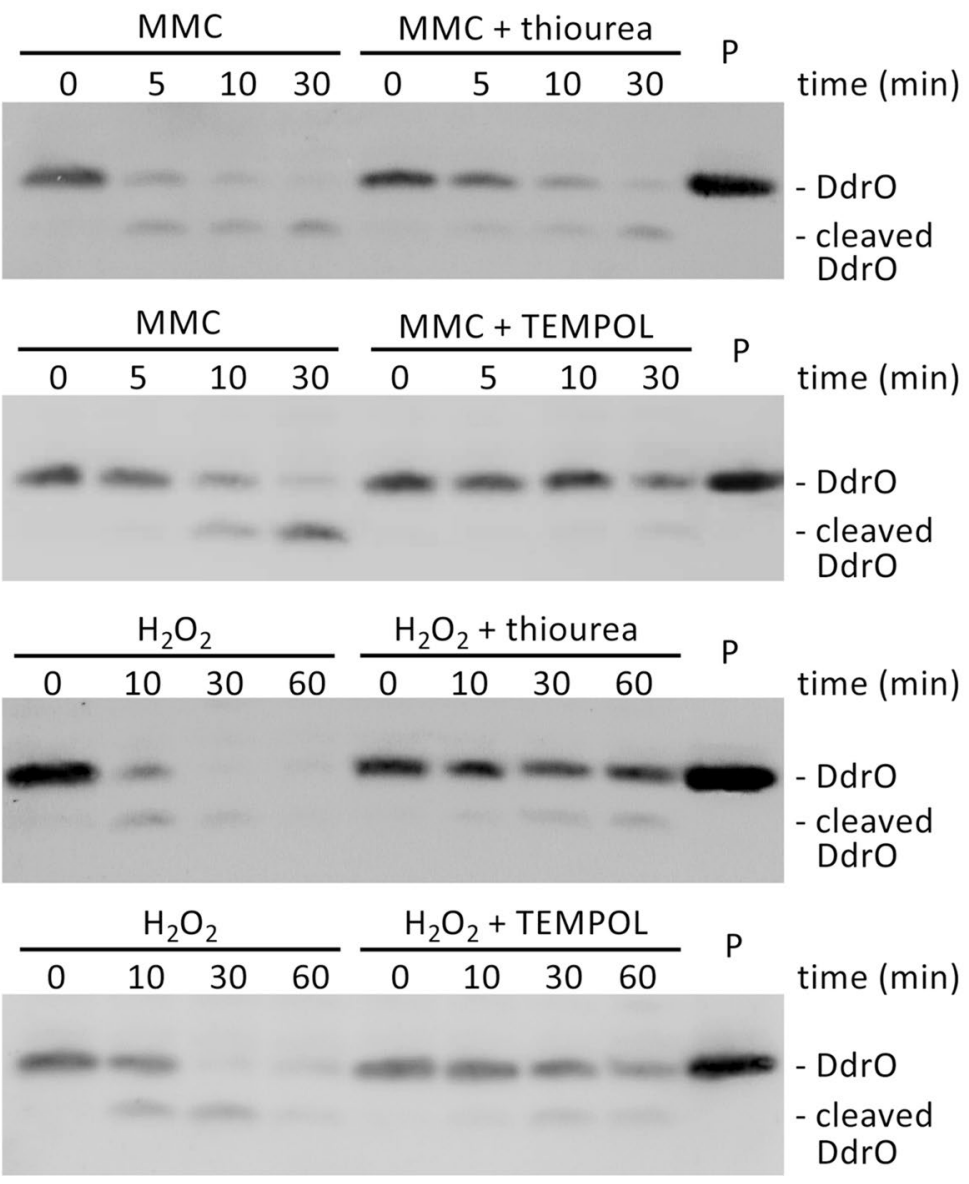

Figure 1. Mitomycin $\mathrm{C}$ and $\mathrm{H}_{2} \mathrm{O}_{2}$ induce DdrO cleavage in $D$. deserti. Wild-type cells were exposed to MMC $(0.5 \mu \mathrm{g} / \mathrm{ml})$ or $\mathrm{H}_{2} \mathrm{O}_{2}(10 \mathrm{mM})$ for the indicated time in the absence or presence of the antioxidants thiourea $(150 \mathrm{mM})$ or TEMPOL $(10 \mathrm{mM})$, and DdrO cleavage was analyzed by immunoblotting. P, $20 \mathrm{ng}$ purified DdrO $(129 \mathrm{aa}, 14.7 \mathrm{kDa})$. Each cropped blot corresponds to a single independent blot; the four uncropped blots are shown in Supplementary Fig. S9.

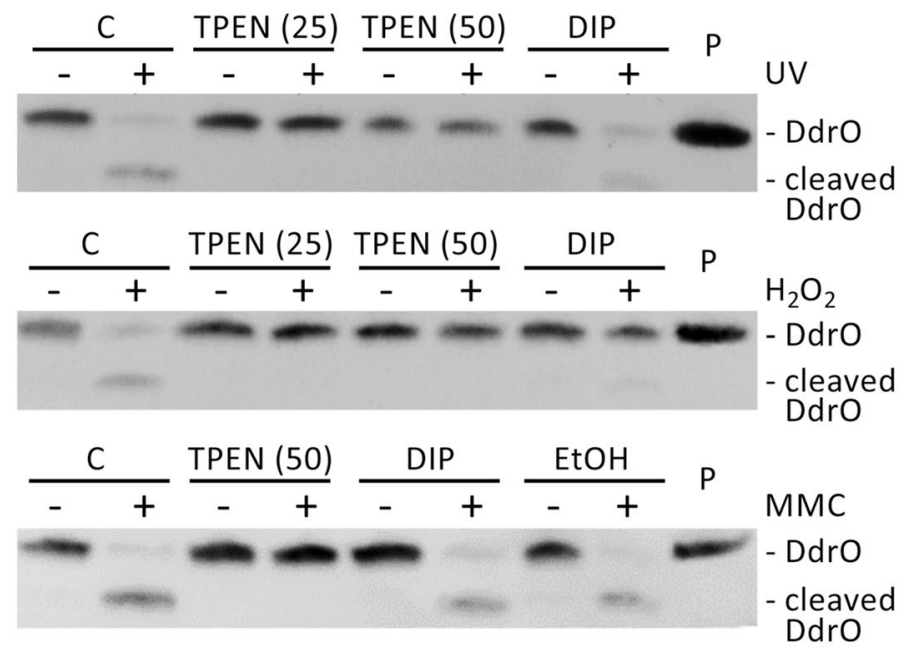

Figure 2. Stress-induced DdrO cleavage in $D$. deserti requires zinc ions. D. deserti strain RD19 (wild type) was exposed or not to UV $\left(250 \mathrm{~J} / \mathrm{m}^{2}\right), \mathrm{H}_{2} \mathrm{O}_{2}(10 \mathrm{mM}$ for $10 \mathrm{~min})$ or MMC $(1 \mu \mathrm{g} / \mathrm{ml}$ for $10 \mathrm{~min})$ in the presence of the $\mathrm{Zn}^{2+}$ chelator TPEN $(25$ or $50 \mu \mathrm{M})$ or the $\mathrm{Fe}^{2+}$ chelator DIP $(500 \mu \mathrm{M})$, and DdrO cleavage was analyzed by immunoblotting. Because TPEN was dissolved in ethanol (EtOH), a control with EtOH (0.5\% final concentration) was included. C, control without metal chelator. P, 20 ng purified DdrO. Each cropped blot corresponds to a single independent blot; the three uncropped blots are shown in Supplementary Fig. S9. 
a

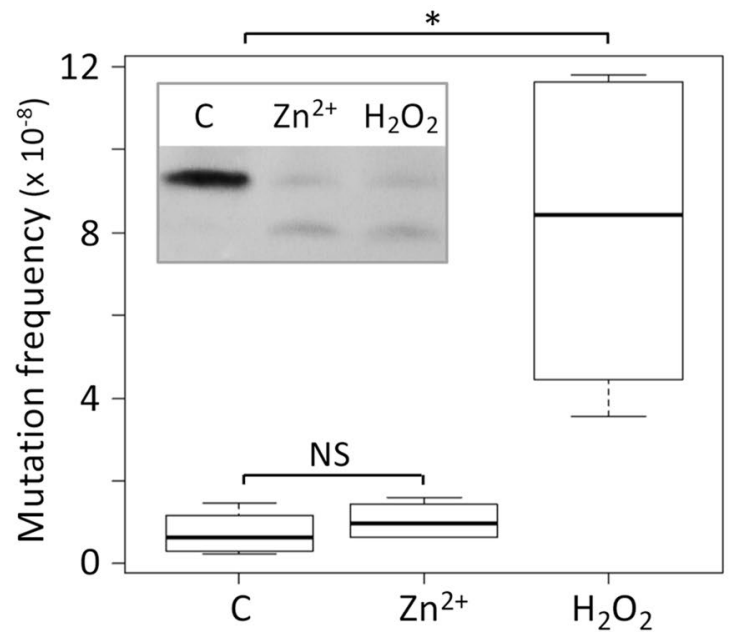

b

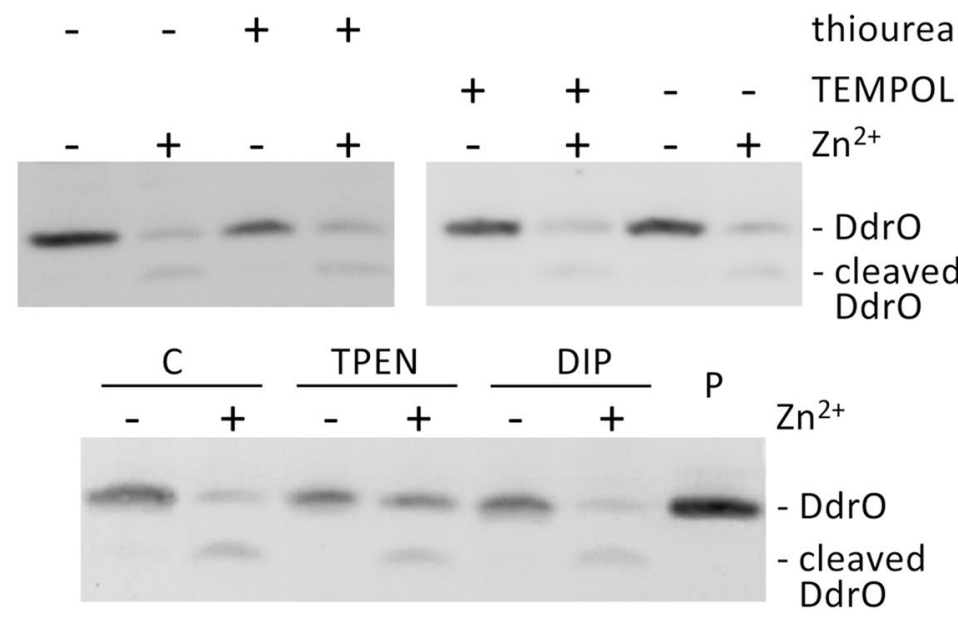

Figure 3. The zinc shock activates IrrE without generating ROS and DNA damage. (a) Induced mutagenesis experiments showing that the zinc shock-induced DdrO cleavage does not occur indirectly via DNA damage/ oxidative stress. In contrast to the $\mathrm{H}_{2} \mathrm{O}_{2}$ exposure ( $10 \mathrm{mM}$ for $\left.10 \mathrm{~min}\right)$, the zinc shock ( $250 \mu \mathrm{M}$ for $\left.10 \mathrm{~min}\right)$ does not lead to an increase in DNA mutations, whereas both conditions induce DdrO cleavage (inlay). C, untreated control cells. A two-sided Mann-Whitney $\mathrm{U}$ test was performed on the data, and an asterisk indicates a $p$ value $<0.05$. NS, not significant. In box plots: center line, median; box limits, upper and lower quartiles; whiskers, $1.5 \times$ interquartile range. (b) Western blots showing that DdrO cleavage induced by the zinc shock $(250 \mu \mathrm{M}$ for $10 \mathrm{~min})$ is neither inhibited by antioxidants thiourea $(150 \mathrm{mM})$ and TEMPOL $(10 \mathrm{mM})$ nor by the $\mathrm{Fe}^{2+}$ chelator DIP $(500 \mu \mathrm{M})$. The $\mathrm{Zn}^{2+}$ chelator TPEN $(50 \mu \mathrm{M})$ partially inhibited the zinc shock-induced cleavage. C, control cells without metal chelator. P, 20 ng purified DdrO. Each cropped blot corresponds to a single independent blot; the four uncropped blots are shown in Supplementary Fig. S9.

suggested that $\mathrm{Mn}^{2+}$ might be the co-factor required for IrrE activity in vivo in Deinococcus ${ }^{20}$. However, the applied TPEN concentrations are low compared to the near-millimolar concentration of $\mathrm{Mn}^{2+}$ in Deinococcus, and the affinity of TPEN for $\mathrm{Zn}^{2+}\left(2.6 \times 10^{-16} \mathrm{M}\right)$ is much higher than for $\mathrm{Mn}^{2+}\left(5.4 \times 10^{-11} \mathrm{M}\right)^{45}$. Together, the data strongly support that the in vivo protease activity of IrrE is dependent on zinc ions.

The zinc shock-induced cleavage is not accompanied by ROS production and DNA damage. Next, we analyzed whether the zinc shock-induced cleavage occurs indirectly via generation of ROS and/or DNA damage. We have previously shown that exposure of $D$. deserti to radiation results in an increase of point mutations as detected by an increased number of rifampicin resistant mutants ${ }^{46}$. Such mutations can arise through direct DNA damage or after incorporation of oxidized nucleotides. Efficient cleavage of DdrO was observed when $D$. deserti was exposed to either zinc shock or $\mathrm{H}_{2} \mathrm{O}_{2}$ treatment. However, in contrast to $\mathrm{H}_{2} \mathrm{O}_{2}$ exposure, zinc shock was not accompanied by induced mutagenesis (Fig. 3a). In addition, ROS were not detected following the zinc shock when a fluorescent ROS detector was used (Supplementary Fig. S4). These results indicate that DdrO cleavage by IrrE after the zinc shock is induced directly by the sudden increase of the $\mathrm{Zn}^{2+}$ concentration, and not indirectly via the generation of ROS and DNA damage. An increase in intracellular free $\mathrm{Zn}^{2+}$ following zinc shock was indeed observed using Fluozin-3 AM, a membrane-permeable molecule that 


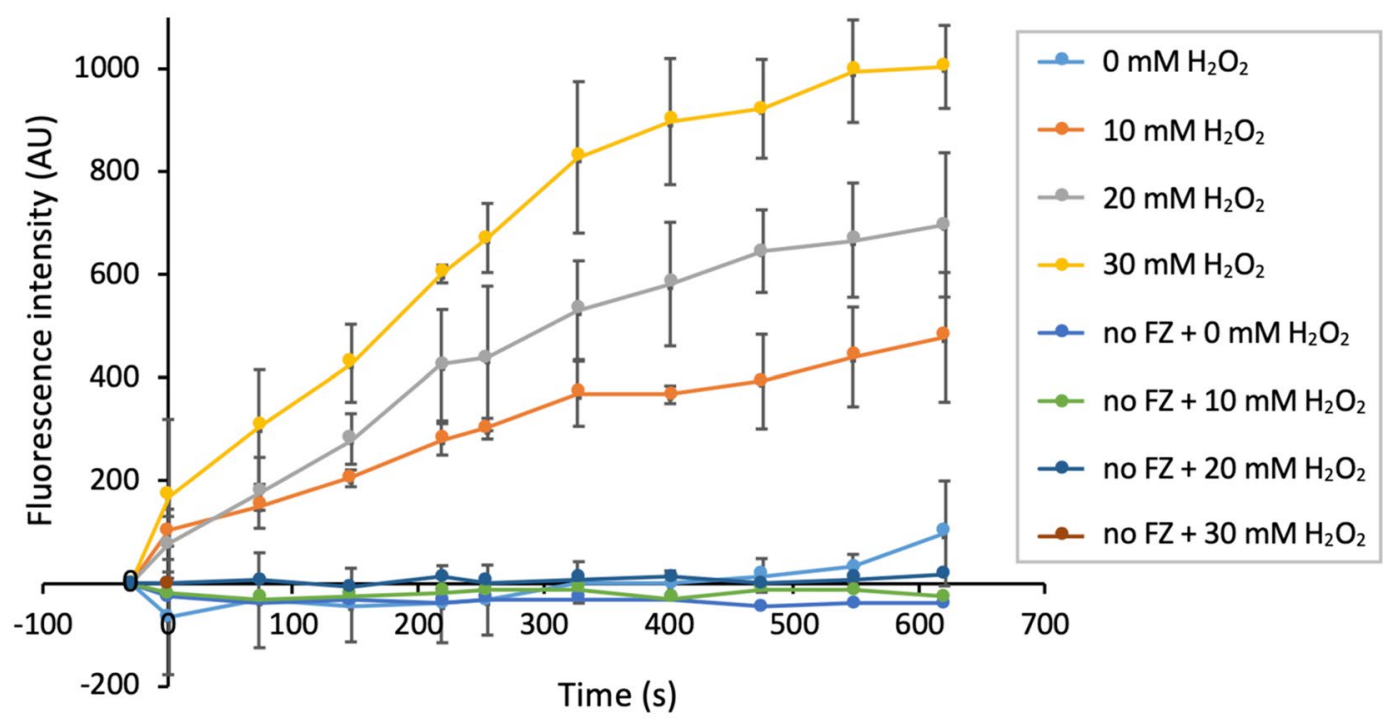

Figure 4. Detection of free intracellular zinc in D. deserti after $\mathrm{H}_{2} \mathrm{O}_{2}$ exposure. After de-esterification of FluoZin-3 AM in the cells, increase of free intracellular zinc was measured after addition of $\mathrm{H}_{2} \mathrm{O}_{2}$. The values are corrected for the fluorescence observed after the incubation for $60 \mathrm{~min}$ with FluoZin-3 AM but before $\mathrm{H}_{2} \mathrm{O}_{2}$ treatment. This observed fluorescence indicates that FluoZin-3 chelates intracellular $\mathrm{Zn}^{2+}$ already before treatment. Error bars are standard deviation of three independent experiments (biological replicates). no FZ, cells incubated without FluoZin-3 AM.

after de-esterification in the cell can detect $\mathrm{Zn}^{2+}$ (Supplementary Fig. S5). The direct activation by $\mathrm{Zn}^{2+}$ is further supported by the observation that the antioxidants thiourea and TEMPOL did not inhibit the zinc-induced DdrO cleavage (Fig. 3b). Moreover, also dipyridyl did not inhibit the zinc-induced cleavage, showing that this induction did not occur indirectly via a step that involves $\mathrm{Fe}^{2+}$ (Fig. 3b).

The direct stimulation of IrrE-mediated DdrO cleavage by zinc ions suggests that radiation/redox-induced cleavage may also involve an increase in free zinc ions. A ROS-induced increase in intracellular free zinc ions is strongly supported by several previous studies. Indeed, many oxidants and other reactive species can cause rapid release of zinc ions from redox-sensitive cysteine-containing zinc sites such as zinc fingers and related structures in proteins, which allows novel interactions between zinc ions and other proteins $s^{31,33,34,47-49}$. Therefore, we hypothesized that oxidative treatments leading to DdrO cleavage, such as exposure to $\mathrm{H}_{2} \mathrm{O}_{2}$, could modify the free zinc ion content in Deinococcus. Using Fluozin-3 AM we showed that $\mathrm{H}_{2} \mathrm{O}_{2}$ concentrations in the range of 10 to $30 \mathrm{mM}$ indeed lead to substantial increases in the level of free zinc ions (Fig. 4). These data strongly support a role for zinc in oxidative-stress-induced activation of IrrE.

Identification of Deinococcus deserti proteins with zinc/cysteine sites. This section describes possible sources of ROS-induced zinc mobilization in D. deserti. In addition to zinc/cysteine (Zn/Cys) sites in proteins, zinc ions can be bound by bacillithiol (BSH), a low-molecular-weight thiol produced by Deinococcus and several other bacteria, with oxidation of BSH (to BSSB) causing release of the zinc ${ }^{50}$. The zinc bound to BSH could thus be an important source for IrrE in oxidative conditions. However, with respect to DdrO cleavage upon stress and DdrO re-accumulation during recovery, no difference was observed between wild-type and BSH biosynthesis deficient mutant strains of $D$. deserti (Supplementary Fig. S6), showing that BSH is not crucial for regulating IrrE activity.

Release of zinc ions from $\mathrm{Zn} / \mathrm{Cys}$ sites after oxidation or other modifications of the $\mathrm{Zn}^{2+}$-coordinating thiolates has been reported for several bacterial proteins ${ }^{49,51}$. Numerous proteins that bind zinc through Cys residues, or through a combination of Cys and histidine (His) residues, have been described or predicted. The zinc-binding residues are generally present as two pairs of closely spaced Cys/His (e.g. the most frequently found CXXC motif, but also others such as CXC, CXXXC and CXXH) separated by a longer spacer within the protein sequence 35,52 . To find $D$. deserti proteins that could be potential sources of oxidative stress-induced increase of intracellular free zinc, we searched its genome for proteins containing $\mathrm{Zn} / \mathrm{Cys}$ sites. We found that it encodes homologs of at least 62 proteins harboring Zn/Cys sites (Supplementary Table S1), with a large fraction (27\%) consisting of proteins involved in DNA replication and repair (Table 1). Similar Cys motifs and thus potential Zn/Cys sites are present in more than 30 additional $D$. deserti proteins, including uncharacterized small proteins containing four or more cysteine residues (e.g. the radiation-induced 74-residue-long DdrS with two CXXC motifs) (Supplementary Table S1). In a $d d r S$ mutant, no difference was observed for DdrO cleavage induction upon stress when compared to the wild-type strain (Supplementary Fig. S6). Taking into consideration all these data, we presume that zinc ions are released from various different proteins following disturbed redox homeostasis. Indeed, the list of identified $\mathrm{Zn} /$ Cys site-containing D. deserti proteins (Supplementary Table S1) contains homologs of at least 


\begin{tabular}{|l|l|l|}
\hline Label & Gene & Description \\
\hline Deide_00480 & priA & Probable primosomal protein N' (ATP-dependent helicase PriA) \\
\hline Deide_01610 & $d n a X$ & DNA polymerase III subunit gamma/tau \\
\hline Deide_02040 & & DEAD/DEAH box helicase-like protein \\
\hline Deide_04900 & $d n a G$ & DNA primase \\
\hline Deide_06340 & recR & Recombination protein RecR \\
\hline Deide_06510 & & ATP-dependent DNA helicase \\
\hline Deide_08980 & & Putative DNA/RNA helicase, SNF2 family \\
\hline Deide_11320 & recQ & ATP-dependent DNA helicase RecQ \\
\hline Deide_12290 & ligA2 & DNA ligase 2 \\
\hline Deide_12660 & radA & DNA repair protein RadA \\
\hline Deide_12760 & $u v r A 1$ & UvrABC system protein A (UvrA protein) \\
\hline Deide_13810 & recO & DNA repair protein RecO \\
\hline Deide_16240 & fpg & Formamidopyrimidine-DNA glycosylase (Fapy-DNA glycosylase) \\
\hline Deide_21710 & & putative DNA polymerase III subunit delta' \\
\hline Deide_1p00290 & ligA1 & DNA ligase 1 \\
\hline Deide_1p01280 & & ATP-dependent DNA helicase RecQ-like \\
\hline Deide_2p02060 & $u v r A 2$ & UvrABC system protein A (UvrA protein) \\
\hline
\end{tabular}

Table 1. DNA replication and repair proteins with zinc/cysteine sites in D. deserti.

10 proteins known to release zinc in stress conditions: Hsp33, Trx2, FUR family proteins, DnaG, PriA, QueC, RpoC, ThrS, AlaS, ClpX ${ }^{49,51}$.

The GAF-like domain of IrrE is not essential to induce DdrO cleavage. The results described above indicate that IrrE protease activity is stimulated by increased availability of zinc ions following exposure to radiation and other agents that cause ROS production and redox imbalance. Then what could be the role of the C-terminal GAF-like domain of IrrE? GAF domains may bind small signaling molecules or may have a role in protein-protein interactions ${ }^{25,26}$. IrrE/DdrO-related systems are found in other bacteria, but a GAF-like domain is not present in all IrrE-like proteins ${ }^{19}$. Therefore, it is interesting to investigate whether or not this domain plays a role in relation with zinc signaling. When a truncated IrrE lacking this domain was co-expressed with DdrO in E. coli, DdrO cleavage was observed (Fig. 5a), showing that the GAF-like domain is not strictly necessary for the cleavage by the N-terminal zinc peptidase domain. Nevertheless, the cleavage was clearly less efficient than with entire IrrE. The truncated IrrE could not be purified from E. coli, indicating that the C-terminal domain has at least a structural role important for protein stability, and possibly contributes in the interaction with DdrO, as suggested by modeling of the IrrE-DdrO complex (Supplementary Fig. S7) ${ }^{19}$. IrrE lacking its C-terminal domain was also expressed, under control of the irrE promoter, in a D. deserti irrE deletion mutant. Strikingly, some DdrO cleavage was observed after exposure of the cells to zinc shock, showing that the GAF-like domain is not absolutely required for the induction of IrrE protease activity in D. deserti (Fig. 5b; Supplementary Fig. S8).

\section{Discussion}

The deinococcal $i r r E$ and $d d r O$ genes have been described for the first time more than 15 years ago, with irrE being required for radiation resistance and radiation-induced expression of $r e c A^{53}$, and $d d r O$ as one of the genes highly induced after radiation or desiccation ${ }^{16}$. The precise function of IrrE and DdrO remained unknown for many years until we showed that IrrE and DdrO function together, which led to the description of a novel stress response mechanism where metalloprotease IrrE cleaves and inactivates transcriptional repressor DdrO when the cells are exposed to radiation ${ }^{14}$, thereby inducing expression of RDR regulon genes (e.g. recA and other DNA repair genes $)^{17}$. Very recently we showed that DdrO consists of two domains: the predicted N-terminal DNA-binding domain, and a C-terminal dimerization domain showing a new fold ${ }^{19}$. Cleavage of this $\mathrm{C}$-terminal domain by IrrE abolishes dimerization and DNA binding of DdrO. Insight in the protease activity of IrrE in Deinococcus, and its stimulation, was obtained in the present study, offering a more complete view of the regulatory mechanism (Fig. 6). We showed that DdrO cleavage by IrrE in Deinococcus cells is dependent on zinc ions, and, after having investigated several possible activation mechanisms, that this in vivo activity is stimulated directly by an increase in available zinc ions very likely resulting from modification in the cell redox status.

IrrE-mediated DdrO cleavage in Deinococcus is induced after exposure to radiation, desiccation, mitomycin $\mathrm{C}, \mathrm{H}_{2} \mathrm{O}_{2}$ and zinc shock, indicating that these conditions share a common intracellular signal stimulating the cleavage. Radiation, desiccation, mitomycin $\mathrm{C}$ and $\mathrm{H}_{2} \mathrm{O}_{2}$ have in common that they induce DNA damage and oxidative stress $^{6}$. The latter may involve formation of oxygen-radical species through the $\mathrm{Fe}^{2+}$-catalyzed Fenton reaction. However, the zinc shock-induced DdrO cleavage was not accompanied by DNA damage or ROS production and was not inhibited by an $\mathrm{Fe}^{2+}$ chelator.

Many proteins and enzymes bind $\mathrm{Zn}^{2+}$, this ion usually having a catalytic or structural role. At catalytic sites, such as in IrrE, the zinc ion is often bound to histidine, glutamic acid and aspartic acid residues. At structural sites, the $\mathrm{Zn}^{2+}$ is often bound to the thiolates of four cysteines (e.g. two pairs of the CXXC motif) or to a 

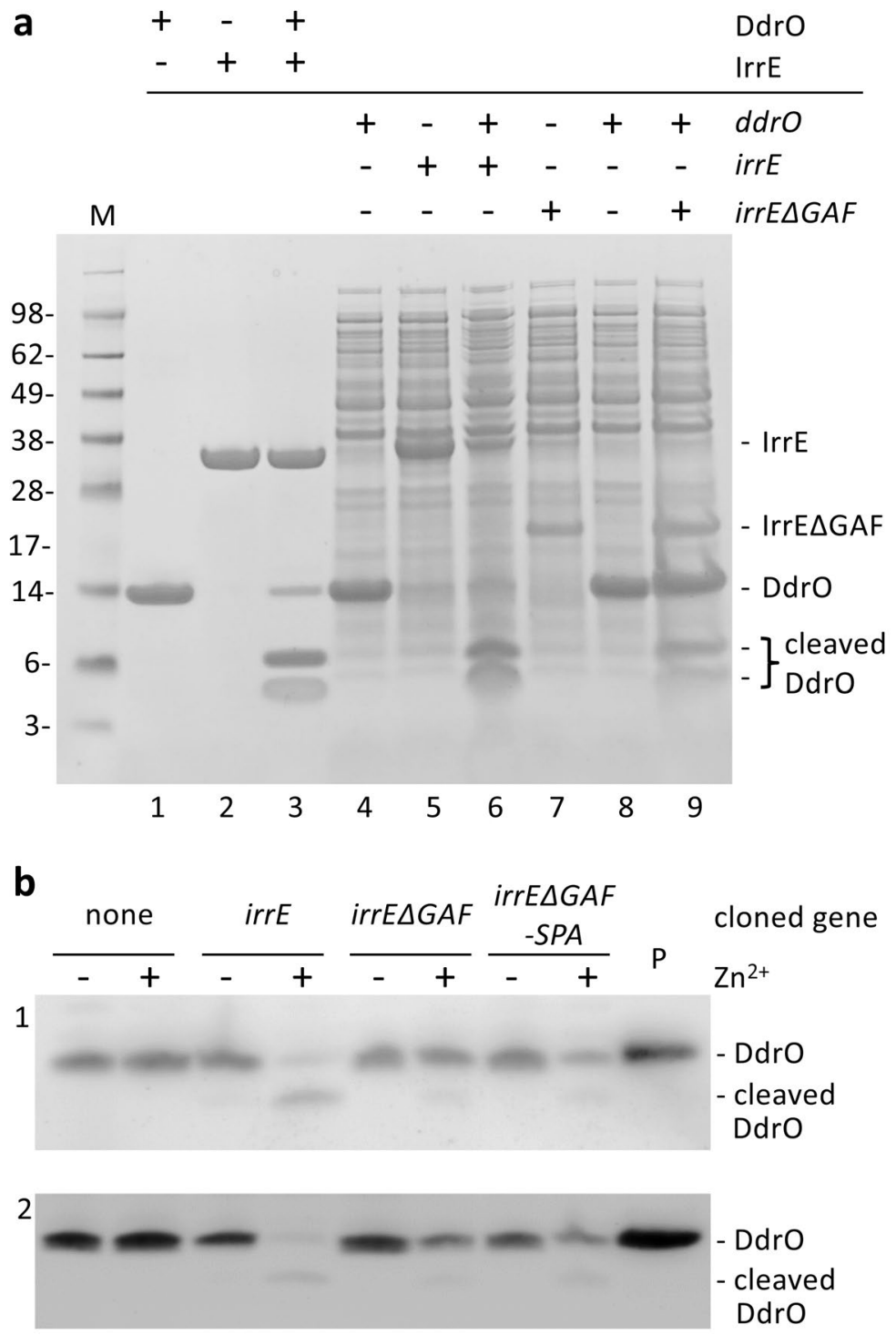

Figure 5. DdrO cleavage by a truncated IrrE lacking its GAF-like domain. (a) SDS-PAGE showing cleavage of DdrO when co-expressed with IrrE or IrrE lacking its GAF-like domain (IrrE $\triangle \mathrm{GAF}$ ) in E. coli (lanes 4 to 9). The same gel contains purified DdrO (lane 1), IrrE (lane 2) and the products of in vitro cleavage $\left(10 \mathrm{~min} 37^{\circ} \mathrm{C}\right.$; lane 3). IrrE and IrrE $\triangle$ GAF have an N-terminal His-tag, DdrO a C-terminal His-tag. M, molecular weight marker proteins (masses in $\mathrm{kDa}$ ). (b) Western blots showing induced cleavage of DdrO by $\operatorname{IrE} \Delta \mathrm{GAF}$ in $D$. deserti. Strain RD42 ( $\triangle$ irrE) was transformed with a derivative of plasmid pI3 containing the indicated cloned gene, and DdrO cleavage was analyzed after zinc shock (250 $\mu \mathrm{M}$ for $10 \mathrm{~min})$. In IrrE $\Delta$ GAF-SPA, the GAF-like domain is replaced by a SPA-tag. Except for the strain without cloned gene, induced DdrO cleavage is (faintly) visible in each strain (appearance of cleavage product and decrease of intact DdrO). The cropped blots (1 and 2) are from two independent series of experiments (uncropped blots are shown in Supplementary Fig. S9). A third independent experiment is shown in Supplementary Fig. S8. P, 20 ng purified DdrO.

combination of cysteine and histidine residues ${ }^{35,52}$. Such zinc-binding residue pairs may also be part of a protein dimer interface ${ }^{34}$, as proposed, for example, regarding dimerization of the DNA repair protein SbcC through a zinc-bridge coordinated by CXXC motifs of two monomers ${ }^{49}$. Impaired redox homeostasis and increased ROS content can result in oxidation of the thiolates that coordinate $\mathrm{Zn}^{2+}$ and destroy the $\mathrm{Zn}^{2+}$-binding site, resulting in rapid release of zinc ions that can subsequently bind to other proteins ${ }^{31,33,34}$. Oxidation or other modifications of the zinc-bound thiolate may occur directly by various ROS or other reactive species ${ }^{33,34,47,48}$, or indirectly by upstream redox sensors that transmit oxidizing equivalents ${ }^{54-58}$. Hsp33, Trx2, FurS, RsrA, RslA and DksA are examples of bacterial proteins for which oxidative stress-induced zinc release has been reported ${ }^{49,56}$. These proteins have been studied because of their role in sensing and responding to oxidative stress. Their $\mathrm{Zn} / \mathrm{Cys}$ centers function as redox switches, and oxidation/reduction regulates the activity of these proteins. For example, under non-stress condition the four conserved Cys residues of Hsp33 bind a zinc ion and Hsp33 is inactive. 
a

\section{Standard conditions}

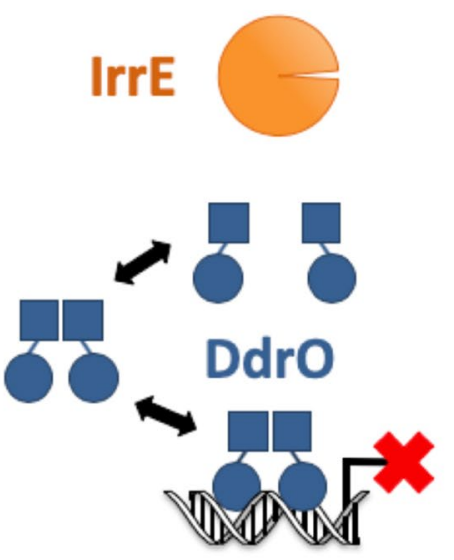

IrrE/DdrO-regulated genes OFF b
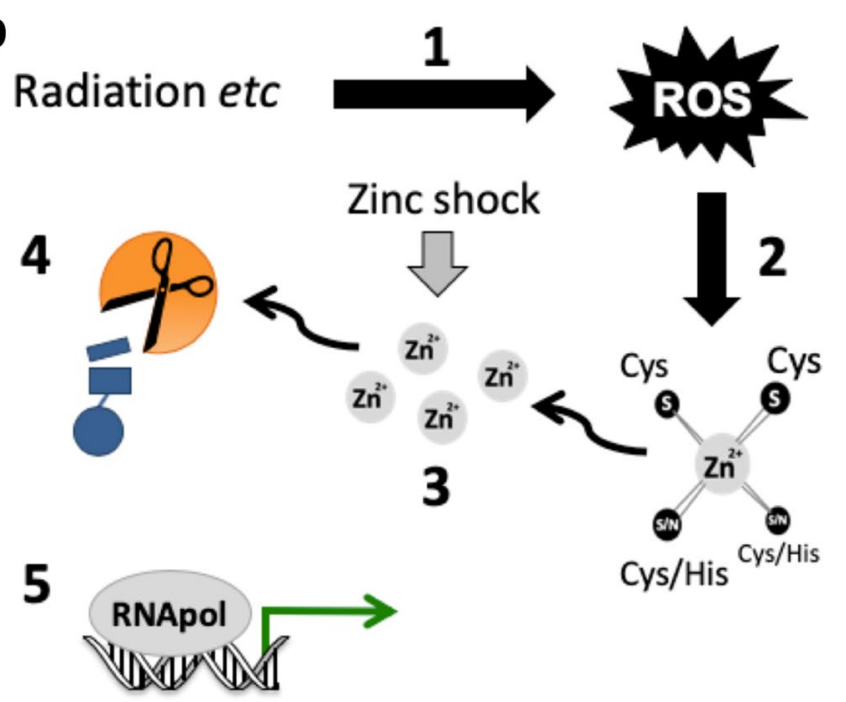

IrrE/DdrO-regulated genes $O N$

^

Survival
(DNA repair)

Figure 6. Proposed model of the IrrE/DdrO-controlled stress response mechanism. (a) Under standard conditions, repressor DdrO exist as a dynamic equilibrium between monomers and free and DNA-bound dimers. DdrO dimerization is mediated by its C-terminal domain. Binding of DdrO dimer to a conserved target DNA motif located in the promoter region of IrrE/DdrO-regulated genes represses their transcription. The majority of metalloprotease IrrE is inactive. (b) Exposure to conditions such as radiation generates oxidative stress through formation of ROS (step 1), which can cause oxidation of cysteine residues of zinc/cysteine sites in proteins (step 2), concomitantly causing release of zinc ions from these sites and a transient increase in the intracellular concentration of free, available zinc ions (step 3). The released zinc functions as second messenger, and increases the amount of active zinc-bound IrrE that cleaves the C-terminal domain of monomeric DdrO (step 4) abolishing its dimerization and shifting the DdrO equilibrium toward cleavable monomers. The diminished amount of DdrO leads to induced expression of the IrrE/DdrO-regulated genes (including several DNA repair genes and $d d r O$ itself) (step 5). A zinc shock directly augments the intracellular free zinc ion concentration. Figure based on data obtained here and previously ${ }^{14,17,19}$.

Oxidants such as $\mathrm{H}_{2} \mathrm{O}_{2}$ and hydroxyl radicals oxidize the $\mathrm{Zn} / \mathrm{Cys}$ center, inducing zinc release and intramolecular disulfide bond formation, and $\mathrm{Hsp} 33$ can acquire its chaperone activity after conformational rearrangement ${ }^{31,59}$. Besides the redox-induced modification of the activity of these proteins, the released zinc may participate in other pathways. Of note, Hsp33 proteins are highly conserved in Deinococcus ${ }^{7}$. Although there are lower levels of $\mathrm{Fe}^{2+}$-catalyzed oxidative protein damage in Deinococcus compared to radiation-sensitive species ${ }^{9}$, it can be assumed that proteins like Hsp33 function in the same way in Deinococcus as in other bacteria, that is, involving oxidation of Cys residues (with concomitant release of zinc ions). Many other Deinococcus proteins, such as FUR family members and Trx2 (see Results), may release zinc upon oxidation of their Zn/Cys sites.

Zinc shock and oxidative stress have thus in common that they transiently augment the intracellular concentration of free zinc ions (i.e. not bound to proteins). We propose that released zinc acts as a second messenger that signals redox imbalance and, by becoming more available to IrrE, increases the amount of active zincbound IrrE to induce the radiation response (Fig. 6). Under standard conditions, bacterial cells maintain an extremely low concentration of free zinc (less than one atom per cell), and most zinc ions are bound to proteins or other molecules ${ }^{60}$. Even a small increase in free zinc can thus be a very potent signal, which can be sensed by zinc-responsive proteins (e.g. IrrE in Deinococcus). A role of released zinc as second messenger in regulation of enzyme activities has been described for eukaryotic cells ${ }^{33-35}$, but such a role in induction of an oxidative stress/ DNA damage response in bacteria has, to our knowledge, not been described previously. Remarkably, many DNA replication and repair proteins have $\mathrm{Zn} /$ Cys sites (Table 1). It is tempting to speculate that destruction of their zinc-binding sites inhibits their function, while the mobilized zinc stimulates IrrE activity and expression of DNA repair genes.

Genes encoding IrrE/DdrO-like protein pairs consisting of a putative metalloprotease (COG2856; ImmA/IrrE family) and a transcriptional regulator (XRE family) have been identified in many bacteria and bacteriophages $^{14,27,29}$. Only a few have been studied experimentally, which showed a stress-induced inactivation of the XRE family repressor by the COG2856 domain-containing protein, resulting in induction of prophage or transposon excision ${ }^{27,28,61,62}$. In each case, however, it is unclear how stress activates the COG2856 protein. Of note, these other studied COG2856 domain proteins are smaller than IrrE and, unlike IrrE, do not contain 
an additional GAF-like domain ${ }^{19}$. As we observed protease activation of truncated IrrE lacking the GAF-like domain, this supports the proposed mechanism of IrrE activation and suggests that oxidative stress-induced release of zinc may also be involved in activation of GAF-lacking IrrE-like proteins. One of these metalloproteases, MpaR in Listeria monocytogenes, was found to be activated during intracellular growth of this pathogen in macrophages ${ }^{61}$, during which bacteria experience oxidative and nitrosative stress. Activated MpaR triggers excision of a prophage, thereby promoting virulence of $L$. monocytogenes ${ }^{61}$. The potential role of zinc signaling in MpaR activation is supported by another recent study that showed that nitric oxide produced by macrophages causes release of zinc from $\mathrm{Zn} / \mathrm{Cys}$ sites of at least 15 proteins in the pathogen Salmonella enteritica ${ }^{51}$, including homologs of eight $\mathrm{Zn} / \mathrm{Cys}$ site-containing proteins conserved in Deinococcus. The COG2856 protein Rir in Streptococcus thermophilus, a species used dairy industry, is involved in prophage induction causing cell lysis by interacting with and preventing oligomerization of repressor Crh without proteolytic cleavage of the latter, despite the presence of a predicted HEXXH zinc-binding active site in $\mathrm{Rir}^{28}$. In this case, it can be hypothesized that zinc binding stabilizes Rir or the Rir/Crh interaction. Taken together, a role for zinc as second messenger following stress exposure of bacteria may be more universal than currently recognized.

\section{Methods}

Growth media and culture conditions. The strains used in this study are listed in Supplementary Table S2. E. coli was grown in Luria-Bertani (LB) at $37^{\circ} \mathrm{C}$. D. deserti and D. radiodurans were grown at $30^{\circ} \mathrm{C}$ in tenfold diluted Tryptic Soy Broth (Fluka, Sigma-Aldrich, T8907) (TSB/10) supplemented with trace elements ${ }^{22}$ or on agar (1.6\%) plates containing the same growth medium. Antibiotics were used at the following concentrations for $D$. deserti: streptomycin, $10 \mu \mathrm{g} \mathrm{ml}^{-1}$; kanamycin, $10 \mu \mathrm{g} \mathrm{ml}^{-1}$; chloramphenicol, $2 \mu \mathrm{g} \mathrm{ml}^{-1}$. For E. coli, the antibiotics concentrations were: kanamycin, $50 \mu \mathrm{g} \mathrm{ml}^{-1}$; ampicillin, $100 \mu \mathrm{g} \mathrm{ml}^{-1}$.

Plasmids and DNA manipulations. Plasmids used are listed in Supplementary Table S3. Standard molecular biology techniques were used to construct plasmids. PCR products obtained with primers that included restriction sites were cloned in pCR4Blunt-TOPO prior to recloning in the desired vector. All cloned PCR fragments and site-directed mutations were analyzed by DNA sequencing to verify absence of potential PCR errors. Primer sequences are listed in Supplementary Table S4. D. deserti genes cloned in the E. coli expression vectors pET-TEV and pET22b are under control of the T7 promoter. Point mutations in IrrE (M18V, M243L and $\mathrm{C116 \textrm {A }}$ ) were introduced in pRD48, which contains an XbaI-HindIII fragment with irrE and its promoter region, using the QuikChange II Site-Directed Mutagenesis Kit (Stratagene) and appropriate primers. Then the XbaI-HindIII fragments with the mutations were recloned into pI3. The cloned XbaI-HindIII fragment in pI3irrE $\triangle$ GAF contains the promoter of $i r E$ and the region encoding IrrE lacking its C-terminal 114 residues corresponding to the GAF-like domain. A similar DNA fragment is present in pI3-irrE $\triangle$ GAF-SPA, except that it encodes an IrrE protein with its GAF-like domain replaced by a SPA-tag (69 aa) to render the truncated IrrE potentially more stable. The fusion of IrrE $\triangle$ GAF with the SPA-tag was obtained with fusion PCR. The different pI3 plasmids were used to transform $D$. deserti RD42 as described previously ${ }^{46}$.

Exposure to $\mathrm{UV}, \mathrm{H}_{2} \mathrm{O}_{2}, \mathrm{MMC}$ or zinc shock. Deinococcus strains grown to $\mathrm{OD}_{600} 0.4$ were exposed to zinc shock, $\mathrm{H}_{2} \mathrm{O}_{2}$, MMC or UV radiation (gamma radiation facilities in our institute have been dismantled). For UV irradiation, portions of $5 \mathrm{ml}$ of the culture were exposed (in a Petri dish without lid) to UV-C (254 nm) using a Bio-Link BLX (Vilber Lourmat). After UV irradiation, cells were incubated at $30^{\circ} \mathrm{C}$ for 10 min (or other times if indicated in the figures). For other exposures, $\mathrm{H}_{2} \mathrm{O}_{2}$ (Riedel-de Haën, 18312), MMC (Sigma-Aldrich, M0440), $\mathrm{ZnCl}_{2}$ (Sigma-Aldrich, 229997) or $\mathrm{MnCl}_{2}$ (Prolabo, 25222.233) was added to $10 \mathrm{ml}$ of culture and incubation was continued (final concentrations and incubation times as indicated in the figures).

Exposure to these agents was also performed in the presence of metal chelators (TPEN for $\mathrm{Zn}^{2+}$, or DIP for $\mathrm{Fe}^{2+}$ ) or antioxidants (thiourea or TEMPOL) that were added at final concentrations as used previously ${ }^{41,63,64}$. For this, bacteria were grown to $\mathrm{OD}_{600} 0.4$ and then either 10-50 $\mu \mathrm{M}$ TPEN (N,N,N',N'-tetrakis(2-pyridinylmethyl)1,2-ethanediamine; Sigma-Aldrich, P4413), $500 \mu$ M DIP (2,2'-dipyridyl; Sigma-Aldrich, D216305), 150 mM thiourea (Sigma-Aldrich, T7875), or 10 mM TEMPOL (4-hydroxy-2,2,6,6-tetramethylpiperidin-1-oxyl; SigmaAldrich, 581500) was added and incubation was continued for $30 \mathrm{~min}$ before the cells were exposed to zinc shock, UV, $\mathrm{H}_{2} \mathrm{O}_{2}$ or MMC.

After the incubations, cells were collected by centrifugation for $1 \mathrm{~min}$ at $10,000 \mathrm{~g}$ and directly lysed by heating for $10 \mathrm{~min}$ at $95^{\circ} \mathrm{C}$ in Novex NuPAGE LDS Sample Buffer supplemented with Novex NuPAGE Sample Reducing Agent (Invitrogen) (volume corresponding to $100 \mu \mathrm{l}$ sample buffer for $1 \mathrm{ml}$ of culture with an $\mathrm{OD}_{600}$ of 1 ) and by passing through a syringe needle, and then frozen at $-20^{\circ} \mathrm{C}$. Protein separation by SDS-PAGE $(20 \mu \mathrm{l}$ sample per lane) and immunoblotting to analyze DdrO cleavage were performed as described previously ${ }^{14}$. A lane with $20 \mathrm{ng}$ DdrO, purified as described ${ }^{17}$, was included on the Western blots. The experiments were performed in triplicate (biological replicates), and representative results are shown.

Co-expression of IrrE or IrrE $\Delta$ GAF with DdrO in E. coli. Two plasmids were used for co-expression in E. coli: a pET-TEV derivative encoding IrrE or IrrE $\triangle$ GAF (both with N-terminal His-tag) and a pET22b derivative encoding DdrO (with C-terminal His-tag). E. coli BL21 (AI) cells freshly transformed with the two plasmids were grown at $37^{\circ} \mathrm{C}$ overnight to saturation in $10 \mathrm{ml}$ of LB medium containing kanamycin and ampicillin. This pre-culture was used to inoculate (start $\left.\mathrm{OD}_{600} 0.05\right) 100 \mathrm{ml}$ of LB medium with the antibiotics and grown at $37^{\circ} \mathrm{C}$ with aeration. At $\mathrm{OD}_{600}$ of $0.6-0.7$, IPTG $(0.1 \mathrm{mM}$ final concentration) and L-arabinose $(0.2 \%$ final concentration) were added and the cells were further incubated at $37^{\circ} \mathrm{C}$ for $3 \mathrm{~h}$. Five hundred $\mu \mathrm{l}$ of induced cells were taken, centrifuged $\left(10,000 \mathrm{~g}, 2 \mathrm{~min}, 4^{\circ} \mathrm{C}\right)$ and re-suspended in Novex NuPAGE LDS Sample Buffer 
(100 $\mu$ l of sample buffer for $1 \mathrm{ml}$ of culture at $\left.\mathrm{OD}_{600} 1\right)$, and heated for $10 \mathrm{~min}$ at $95^{\circ} \mathrm{C}$. Samples $(20 \mu \mathrm{l}$ per lane) were loaded on SDS-PAGE gels (Novex NuPAGE 10\% Bis-Tris Gels; Invitrogen), and migrated in 1X NuPAGE MES SDS Running Buffer (Invitrogen) for $1 \mathrm{~h}$ at $130 \mathrm{~V}$. In vitro cleavage control was performed as described previously ${ }^{14}$. The proteins were visualized by staining with Imperial protein stain (Pierce).

Induced mutagenesis. D. deserti strains were grown to $\mathrm{OD}_{600} 0.4$ and then $250 \mu \mathrm{M} \mathrm{ZnCl} 2$ or $10 \mathrm{mM} \mathrm{H}_{2} \mathrm{O}_{2}$ or nothing (control) was added, and cultures were incubated further for $10 \mathrm{~min}$ at $30^{\circ} \mathrm{C}$. One part $(1 \mathrm{ml})$ of the cultures was taken to prepare samples for immunoblotting to analyze DdrO cleavage as described above. The other part of the cultures was centrifuged for $5 \mathrm{~min}$ at $5000 \mathrm{~g}$, and the cell pellets were re-suspended in fresh growth medium and incubated for $20 \mathrm{~h}$ at $30^{\circ} \mathrm{C}$ with shaking to permit fixation of mutations. Then $1 \mathrm{ml}$ of each culture were spread in duplicate on plates with $10 \mu \mathrm{g} \mathrm{ml}^{-1}$ rifampicin. In parallel, $0.1 \mathrm{ml}$ of serial dilutions $10^{-6}$ and $10^{-7}$ were spread in duplicate on plates without rifampicin. The entire experiment was performed in triplicate (biological replicates). Colony-forming units (CFU) were determined after incubation for 3-4 days at $30^{\circ} \mathrm{C}$. The mutation frequency was calculated by the ratio "number of $\mathrm{Rif}^{\mathrm{R}} \mathrm{CFU} / \mathrm{ml}$ / " total number of CFU/ml".

Zinc measurements with fluorescent probe FluoZin-3. Experiments to detect free intracellular $\mathrm{Zn}^{2+}$ were based on a previously described protocol ${ }^{65}$. D. deserti was grown to $\mathrm{OD}_{600} 0.4$. Bacteria were resuspended in fresh TSB/10 and then incubated with $5 \mu \mathrm{M}$ FluoZin-3, AM, cell permeant (Thermo Fisher Scientific, F24195) for $60 \mathrm{~min}$ at room temperature in the dark to allow complete de-esterification of intracellular acetoxymethyl (AM) esters. The bacteria were then washed three times in TSB/10. Fluorescence measurements were performed in a microplate at $28{ }^{\circ} \mathrm{C}$ and using a spectrofluorimeter (Infinite 200 Pro; Tecan). After excitation of the sample at $485 \mathrm{~nm}$, fluorescence emission was recorded at $519 \mathrm{~nm}$ before and after addition of $\mathrm{H}_{2} \mathrm{O}_{2}$ or $\mathrm{ZnCl}_{2}$.

ROS measurements with fluorescent probe $\mathbf{H}_{2}$ DCFDA. ROS detection using $\mathrm{H}_{2}$ DCFDA $\left(2^{\prime}, 7^{\prime}\right.$-Dichlorodihydrofluorescein diacetate; Sigma-Aldrich, D6883) was performed after adaptation of a previously described method ${ }^{66}$. D. deserti was grown to $\mathrm{OD}_{600} 0.4$. Bacteria were washed once in $0.85 \% \mathrm{KCl}$ and then incubated with $25 \mu \mathrm{M} \mathrm{H}_{2}$ DCFDA for $60 \mathrm{~min}$ at room temperature in the dark, and then washed again in $0.85 \%$ $\mathrm{KCl}$. Fluorescence measurements were performed in a microplate at $28{ }^{\circ} \mathrm{C}$ and using a spectrofluorimeter (Infinite 200 Pro; Tecan). After excitation of the sample at $480 \mathrm{~nm}$, fluorescence emission was recorded at $526 \mathrm{~nm}$ before and after addition of $\mathrm{H}_{2} \mathrm{O}_{2}$ or $\mathrm{ZnCl}_{2}$.

Construction of $\boldsymbol{D}$. deserti gene deletion mutants. $\quad$ D. deserti strains in which $d d r S$ (Deide_04721), bshA (Deide_11680) or bshC (Deide_13730) are deleted and replaced by a kanamycin resistance gene, were constructed as described previously for other deletion mutants ${ }^{46}$. Briefly, DNA fragments corresponding to upstream and downstream regions of the gene to be deleted, were cloned upstream and downstream of a kanamycin resistance cassette in a pUC19 derivative. Resulting plasmids, which do not replicate in $D$. deserti, were introduced in $D$. deserti, and double homologous recombination events and complete deletion of the gene of interest were verified by diagnostic PCR.

\section{Data availability}

The IrrE and DdrO genes and proteins in this study correspond to SwissProt entries C1CZ84 and C1CYP4, respectively. All data that support the findings of this study are available from the corresponding author on request.

Received: 22 October 2020; Accepted: 11 February 2021

Published online: 25 February 2021

\section{References}

1. Baharoglu, Z. \& Mazel, D. SOS, the formidable strategy of bacteria against aggressions. FEMS Microbiol. Rev. 38, 1126-1145 (2014).

2. Kreuzer, K. N. DNA damage responses in prokaryotes: Regulating gene expression, modulating growth patterns, and manipulating replication forks. Cold Spring Harb. Perspect. Biol. 5, a012674 (2013).

3. Battista, J. R. Against all odds: The survival strategies of Deinococcus radiodurans. Annu. Rev. Microbiol. 51, 203-224 (1997).

4. Cox, M. M. \& Battista, J. R. Deinococcus radiodurans-The consummate survivor. Nat. Rev. Microbiol. 3, 882-892 (2005).

5. de Groot, A. et al. Alliance of proteomics and genomics to unravel the specificities of Sahara bacterium Deinococcus deserti. PLoS Genet. 5, e1000434 (2009).

6. Slade, D. \& Radman, M. Oxidative stress resistance in Deinococcus radiodurans. Microbiol. Mol. Biol. Rev. 75, 133-191 (2011)

7. Lim, S., Jung, J.-H., Blanchard, L. \& de Groot, A. Conservation and diversity of radiation and oxidative stress resistance mechanisms in Deinococcus species. FEMS Microbiol. Rev. 43, 19-52 (2019).

8. Daly, M. J. Death by protein damage in irradiated cells. DNA Repair. 11, 12-21 (2012).

9. Daly, M. J. et al. Protein oxidation implicated as the primary determinant of bacterial radioresistance. PLoS Biol. 5, e92 (2007).

10. Krisko, A. \& Radman, M. Protein damage and death by radiation in Escherichia coli and Deinococcus radiodurans. Proc. Natl. Acad. Sci. USA 107, 14373-14377 (2010).

11. Daly, M. J. et al. Accumulation of $\mathrm{Mn}$ (II) in Deinococcus radiodurans facilitates gamma-radiation resistance. Science 306, 1025-1028 (2004).

12. Daly, M. J. et al. Small-molecule antioxidant proteome-shields in Deinococcus radiodurans. PLoS ONE 5, e12570 (2010).

13. de Groot, A. et al. RNA sequencing and proteogenomics reveal the importance of leaderless mRNAs in the radiation-tolerant bacterium Deinococcus deserti. Genome Biol. Evol. 6, 932-948 (2014).

14. Ludanyi, M. et al. Radiation response in Deinococcus deserti: IrrE is a metalloprotease that cleaves repressor protein DdrO. Mol. Microbiol. 94, 434-449 (2014).

15. Makarova, K. S. et al. Deinococcus geothermalis: the pool of extreme radiation resistance genes shrinks. PLoS ONE 2, e955 (2007). 
16. Tanaka, M. et al. Analysis of Deinococcus radiodurans's transcriptional response to ionizing radiation and desiccation reveals novel proteins that contribute to extreme radioresistance. Genetics 168, 21-33 (2004).

17. Blanchard, L. et al. Conservation and diversity of the IrrE/DdrO-controlled radiation response in radiation-resistant Deinococcus bacteria. Microbiologyopen 6, e477 (2017).

18. Devigne, A. et al. DdrO is an essential protein that regulates the radiation desiccation response and the apoptotic-like cell death in the radioresistant Deinococcus radiodurans bacterium. Mol. Microbiol. 96, 1069-1084 (2015).

19. de Groot, A. et al. Crystal structure of the transcriptional repressor DdrO: Insight into the metalloprotease/repressor-controlled radiation response in Deinococcus. Nucleic Acids Res. 47, 11403-11417 (2019).

20. Wang, Y. et al. Protease activity of PprI facilitates DNA damage response: $\mathrm{Mn}^{2+}$-dependence and substrate sequence-specificity of the proteolytic reaction. PLOS ONE 10, e0122071 (2015).

21. Lewis, R. J., Brannigan, J. A., Offen, W. A., Smith, I. \& Wilkinson, A. J. An evolutionary link between sporulation and prophage induction in the structure of a repressor:Anti-repressor complex. J. Mol. Biol. 283, 907-912 (1998).

22. Vujicic-Zagar, A. et al. Crystal structure of the IrrE protein, a central regulator of DNA damage repair in Deinococcaceae. J. Mol. Biol. 386, 704-716 (2009).

23. Fukasawa, K. M., Hata, T., Ono, Y. \& Hirose, J. Metal preferences of zinc-binding motif on metalloproteases. J. Amino Acids 2011, 574816 (2011).

24. Holmquist, B. \& Vallee, B. L. Metal substitutions and inhibition of thermolysin: spectra of the cobalt enzyme. J. Biol. Chem. 249, 4601-4607 (1974).

25. Shi, R., McDonald, L., Cygler, M. \& Ekiel, I. Coiled-coil helix rotation selects repressing or activating state of transcriptional regulator DhaR. Structure 22, 478-487 (2014).

26. Zoraghi, R., Corbin, J. D. \& Francis, S. H. Properties and functions of GAF domains in cyclic nucleotide phosphodiesterases and other proteins. Mol. Pharmacol. 65, 267-278 (2004).

27. Bose, B., Auchtung, J. M., Lee, C. A. \& Grossman, A. D. A conserved anti-repressor controls horizontal gene transfer by proteolysis. Mol. Microbiol. 70, 570-582 (2008).

28. Koberg, S., Mohamed, M. D. A., Faulhaber, K., Neve, H. \& Heller, K. J. Identification and characterization of cis- and trans-acting elements involved in prophage induction in Streptococcus thermophilus J34. Mol. Microbiol. 98, 535-552 (2015).

29. Makarova, K. S., Wolf, Y. I. \& Koonin, E. V. Comprehensive comparative-genomic analysis of type 2 toxin-antitoxin systems and related mobile stress response systems in prokaryotes. Biol. Direct 4, 19 (2009).

30. Matic, I. The major contribution of the DNA damage-triggered reactive oxygen species production to cell death: Implications for antimicrobial and cancer therapy. Curr. Genet. 64, 567-569 (2018).

31. Ilbert, M., Graf, P. C. \& Jakob, U. Zinc center as redox switch-new function for an old motif. Antioxid. Redox Signal. 8, 835-846 (2006).

32. Imlay, J. A. Transcription factors that defend bacteria against reactive oxygen species. Annu. Rev. Microbiol. 69, 93-108 (2015).

33. Kröncke, K. D. \& Klotz, L. O. Zinc fingers as biologic redox switches?. Antioxid. Redox Signal. 11, 1015-1027 (2009).

34. Maret, W. Zinc coordination environments in proteins as redox sensors and signal transducers. Antioxid. Redox Signal. 8, 1419$1441(2006)$.

35. Wouters, M. A., Fan, S. W. \& Haworth, N. L. Disulfides as redox switches: From molecular mechanisms to functional significance. Antioxid. Redox Signal. 12, 53-91 (2010).

36. Dapa, T., Fleurier, S., Bredeche, M.-F. \& Matic, I. The SOS and RpoS regulons contribute to bacterial cell robustness to genotoxic stress by synergistically regulating DNA polymerase Pol II. Genetics 206, 1349-1360 (2017).

37. Polyakov, N. et al. Redox-active quinone chelators: Properties, mechanisms of action, cell delivery, and cell toxicity. Antioxid. Redox Signal. 28, 1394-1403 (2018).

38. Verweij, J. \& Pinedo, H. M. Mitomycin C: Mechanism of action, usefulness and limitations. Anticancer Drugs 1, 5-13 (1990).

39. Kelner, M. J., Bagnell, R. \& Welch, K. J. Thioureas react with superoxide radicals to yield a sulfhydryl compound. Explanation for protective effect against paraquat. J. Biol. Chem. 265, 1306-1311 (1990).

40. Kohanski, M. A., Dwyer, D. J., Hayete, B., Lawrence, C. A. \& Collins, J. J. A common mechanism of cellular death induced by bactericidal antibiotics. Cell 130, 797-810 (2007).

41. Latifi, A., Jeanjean, R., Lemeille, S., Havaux, M. \& Zhang, C.-C. Iron starvation leads to oxidative stress in Anabaena sp. strain PCC 7120. J. Bacteriol. 187, 6596-6598 (2005).

42. Wilcox, C. S. Effects of tempol and redox-cycling nitroxides in models of oxidative stress. Pharmacol. Ther. 126, 119-145 (2010).

43. Wilcox, C. S. \& Pearlman, A. Chemistry and antihypertensive effects of tempol and other nitroxides. Pharmacol. Rev. 60, 418-469 (2008).

44. Ezraty, B., Gennaris, A., Barras, F. \& Collet, J. F. Oxidative stress, protein damage and repair in bacteria. Nat. Rev. Microbiol. 15, 385-396 (2017).

45. Shumaker, D. K., Vann, L. R., Goldberg, M. W., Allen, T. D. \& Wilson, K. L. TPEN, a $\mathrm{Zn}^{2+} / \mathrm{Fe}^{2+}$ chelator with low affinity for $\mathrm{Ca}^{2+}$, inhibits lamin assembly, destabilizes nuclear architecture and may independently protect nuclei from apoptosis in vitro. Cell Calcium 23, 151-164 (1998).

46. Dulermo, R., Fochesato, S., Blanchard, L. \& de Groot, A. Mutagenic lesion bypass and two functionally different RecA proteins in Deinococcus deserti. Mol. Microbiol. 74, 194-208 (2009).

47. Maret, W. Zinc in cellular regulation: The nature and significance of 'zinc signals'. Int. J. Mol. Sci. 18, 2285 (2017).

48. Maret, W. The redox biology of redox-inert zinc ions. Free Radic. Biol. Med. 134, 311-326 (2019).

49. Ortiz de Orue Lucana, D., Wedderhoff, I. \& Groves, M. R. ROS-mediated signalling in bacteria: zinc-containing Cys-X-X-Cys redox centres and iron-based oxidative stress. J. Signal Transduct. 2012, 605905 (2012).

50. Ma, Z. et al. Bacillithiol is a major buffer of the labile zinc pool in Bacillus subtilis. Mol. Microbiol. 94, 756-770 (2014).

51. Frawley, E. R. et al. Nitric oxide disrupts zinc homeostasis in Salmonella enterica serovar Typhimurium. mBio 9, 66 (2018).

52. Andreini, C., Banci, L., Bertini, I. \& Rosato, A. Zinc through the three domains of life. J. Proteome Res. 5, 3173-3178 (2006).

53. Earl, A. M., Mohundro, M. M., Mian, I. S. \& Battista, J. R. The IrrE protein of Deinococcus radiodurans R1 is a novel regulator of recA expression. J. Bacteriol. 184, 6216-6224 (2002).

54. Boronat, S. et al. Thiol-based $\mathrm{H}_{2} \mathrm{O}_{2}$ signalling in microbial systems. Redox Biol. 2, 395-399 (2014).

55. García-Santamarina, S. et al. Is oxidized thioredoxin a major trigger for cysteine oxidation? Clues from a redox proteomics approach. Antioxid. Redox Signal. 18, 1549-1556 (2013).

56. Kim, J.-S. et al. DksA-DnaJ redox interactions provide a signal for the activation of bacterial RNA polymerase. Proc. Natl. Acad. Sci. USA 115, E11780-E11789 (2018).

57. Stewart, E. J., Aslund, F. \& Beckwith, J. Disulfide bond formation in the Escherichia coli cytoplasm: An in vivo role reversal for the thioredoxins. EMBO J. 17, 5543-5550 (1998).

58. Stöcker, S., Maurer, M., Ruppert, T. \& Dick, T. P. A role for 2-Cys peroxiredoxins in facilitating cytosolic protein thiol oxidation. Nat. Chem. Biol. 14, 148-155 (2018).

59. Ilbert, M. et al. The redox-switch domain of Hsp33 functions as dual stress sensor. Nat. Struct. Mol. Biol. 14, 556-563 (2007).

60. Wang, D., Hosteen, O. \& Fierke, C. A. ZntR-mediated transcription of $z$ tA responds to nanomolar intracellular free zinc. J. Inorg. Biochem. 111, 173-181 (2012).

61. Argov, T. et al. Coordination of cohabiting phage elements supports bacteria-phage cooperation. Nat. Commun. 10, 5288 (2019). 
62. Bose, B. \& Grossman, A. D. Regulation of horizontal gene transfer in Bacillus subtilis by activation of a conserved site-specific protease. J. Bacteriol. 193, 22-29 (2011).

63. Dewachter, L., Herpels, P., Verstraeten, N., Fauvart, M. \& Michiels, J. Reactive oxygen species do not contribute to ObgE ${ }^{\star}$-mediated programmed cell death. Sci. Rep. 6, 33723 (2016).

64. Kashyap, D. R. et al. Peptidoglycan recognition proteins kill bacteria by inducing oxidative, thiol, and metal stress. PLoS Pathog. 10, e1004280 (2014).

65. Bayle, L. et al. Zinc uptake by Streptococcus pneumoniae depends on both AdcA and AdcAII and is essential for normal bacterial morphology and virulence. Mol. Microbiol. 82, 904-916 (2011).

66. Hakkila, K. et al. Oxidative stress and photoinhibition can be separated in the cyanobacterium Synechocystis sp. PCC 6803. Biochim. Biophys. Acta 1837, 217-225 (2014).

\section{Acknowledgements}

We thank R. Dulermo, M. Ludanyi and B. Alonso for construction of some of the strains and plasmids, C. Brutesco for help with fluorescence spectroscopy, F. Confalonieri for helpful discussions, and D. Pignol and C. Carles for constant support. This work was funded by the Transverse Division n ${ }^{\circ} 4$ (Radiobiology) of the French Alternative Energies and Atomic Energy Commission (Programme $n^{\circ} 4$ Radiobiologie) and by a grant from the Agence Nationale de la Recherche (ANR-19-CE12-0010). R.M. was supported by a Phare Ph.D. fellowship from the French Alternative Energies and Atomic Energy Commission.

\section{Author contributions}

R.M. and A.d.G. designed and conceived the experiments. R.M. performed all experiments. L.B. and A.d.G. supervised the execution of the experiments. A.d.G. searched the D. deserti genome for Zn/Cys proteins. R.M., P.R., L.B. and A.d.G analyzed the data. A.d.G. wrote the paper with contributions from R.M., P.R. and L.B. All authors reviewed the manuscript.

\section{Competing interests}

The authors declare no competing interests.

\section{Additional information}

Supplementary Information The online version contains supplementary material available at https://doi. org/10.1038/s41598-021-84026-x.

Correspondence and requests for materials should be addressed to A.G.

Reprints and permissions information is available at www.nature.com/reprints.

Publisher's note Springer Nature remains neutral with regard to jurisdictional claims in published maps and institutional affiliations.

Open Access This article is licensed under a Creative Commons Attribution 4.0 International License, which permits use, sharing, adaptation, distribution and reproduction in any medium or format, as long as you give appropriate credit to the original author(s) and the source, provide a link to the Creative Commons licence, and indicate if changes were made. The images or other third party material in this article are included in the article's Creative Commons licence, unless indicated otherwise in a credit line to the material. If material is not included in the article's Creative Commons licence and your intended use is not permitted by statutory regulation or exceeds the permitted use, you will need to obtain permission directly from the copyright holder. To view a copy of this licence, visit http://creativecommons.org/licenses/by/4.0/.

(C) The Author(s) 2021 